\title{
A Clostridium acetobutylicum regulator gene (regA) affecting amylase production in Bacillus subtilis
}

\author{
Sean P. Davison, Joseph D. Santangelo, Sharon J. Reid and \\ David R. Woods
}

Department of

Microbiology, University of

Cape Town, Rondebosch

7700 , South Africa Author for correspondence: David R. Woods. Tel: +27 21650 2173. Fax: +2721 6504023.
e-mail: AESDRW@BREMNER.UCT.AC.ZA

\begin{abstract}
Plasmid pMET7C containing a 6.05 kb DNA insert from Clostridium acetobutylicum P262 made Escherichia coli F19 cells sensitive to metronidazole. The nucleotide sequence of the $C$. acetobutylicum DNA controlling metronidazole sensitivity in E. coli F19 revealed an ORF of 972 bp which encoded a protein of 324 amino acids with a calculated $M_{r}$ of 35000 . The amino acid sequence encoded by the ORF contained a helix-turn-helix DNAbinding domain and was homologous to the catabolite control protein, CcpA, from Bacillus subtilis and Bacillus megaterium, a tRNA repressor of $E$. coli encoded by the shl gene, and the GalR, Lacl and PurR repressors of $E$. coli. The C. acetobutylicum ORF, which was termed regA, complemented a B. subtilis CCPA mutant and an E. coli shl mutant, but was unable to complement $E$. coli galR, lacl or purR mutants. To determine whether the regA gene product was involved in the regulation of amylase gene expression in C. acetobutylicum, a starch-degrading enzyme gene (staA) from C. acetobutylicum NCIMB 8052 was cloned. The RegA protein inhibited the degradation of starch by the $C$. acetobutylicum staA gene product in $E$. coli.
\end{abstract}

Keywords : Clostridium acetobutylicum, Bacillus subtilis, amylase, metronidazole susceptibility

\section{INTRODUCTION}

Clostridium acetobutylicum is a Gram-positive, endosporeforming, obligate anaerobe which produces acetone, butanol and ethanol from a variety of carbohydrate substrates including starch and molasses. In batch culture, C. acetobutylicum produces hydrogen, carbon dioxide, acetate and butyrate during the initial growth phase (acidogenic phase). The onset of solvent production involves a switch in the carbon flow from the acidproducing pathways to the solvent-producing pathways (solventogenic phase), and is accompanied by morphological changes and the appearance of solvent-forming enzymes (Jones et al., 1982). A second major morphological and physiological differentiation step occurs at the end of the solventogenic phase with the initiation of sporulation. Although the physiological conditions required to trigger solventogenesis (Bahl \& Gottschalk,

The GenBank accession number for the nucleotide sequence reported in this paper is L14685.
1988; Jones \& Woods, 1989; Rogers, 1984) and sporulation (Long et al., 1984a, b) have been investigated, the molecular mechanisms controlling differentiation or substrate utilization remain obscure. $C$. acetobutylicum grows very well on starch but little is known about the starch utilization system(s) or the regulation of the amylase enzymes. Glucose repression of amylase has been reported in C. acetobutylicum 824 (Annous \& Blaschek, 1990).

Plasmid pMET7C was isolated as part of a study on the molecular characterization of genes from $C$. acetobutylicum involved in the electron-transfer system which are able to activate the drug metronidazole in Escherichia coli (Santangelo et al., 1991). The presence of pMET7C rendered E. coli F19 sensitive to metronidazole. In the work described here, nucleotide sequencing and database analysis of the deduced protein sequence of the region affecting metronidazole sensitivity in E. coli indicated that it contained a regulator gene, $\operatorname{reg} A$, which had $40 \%$ identity to the $\operatorname{ccp} A$ gene of Bacillus subtilis. The $\operatorname{reg} A$ gene complemented a $c c p A$ mutant of $B$. subtilis and repressed the expression of a $C$. acetobutylicum gene capable of degrading starch. 


\section{METHODS}

Bacterial strains and growth conditions. The bacterial strains used in this study are listed in Table 1. C. acetobutylicum P262 was grown under strict anaerobic conditions in modified Clostridium basal medium (CBM) (O’Brien \& Morris, 1971) as described by Allcock et al. (1982). E. coli and B. subtilis were grown aerobically in Luria broth (LB) (Sambrook et al., 1989). Anaerobic growth of $E$. coli was carried out in an anaerobic glove box (Forma Scientific). To support growth of E. coli via anaerobic respiration or via fermentation, bacteria were grown respectively in $\mathrm{LB}$ supplemented with $0.2 \%(\mathrm{w} / \mathrm{v}) \mathrm{NaNO}_{3}$ and $0.1 \%(\mathrm{w} / \mathrm{v})$ glucose, or in the complex medium ( $\mathrm{pH} 8.0$ ) described by Clark \& Cronan (1980) supplemented with $1 \%(\mathrm{w} / \mathrm{v})$ glucose.

Plasmid pMET7C. Plasmid pMET7C, isolated by Santangelo $e t$ al. (1991), contained a $6.05 \mathrm{~kb}$ DNA insert from $C$. acetobutylicum in pEcoR251 (Zabeau \& Stanley, 1982). E. coli F19(pMET7C), and was sensitive to $20 \mu \mathrm{g}$ metronidazole $\mathrm{ml}^{-1}$. The region of DNA on pMET7C which was responsible for the increase in sensitivity to metronidazole was termed the $\operatorname{reg} A$ gene (Fig. 1).

Cloning of genes encoding $C$. acetobutylicum starch-degrading enzymes. Gene libraries in pEcoR251 were constructed with DNA isolated from $C$. acetobutylicum P262 and NCIMB 8052 (Zappe et al., 1986). Recombinant pEcoR251 plasmids were selected on LB agar containing starch azure $(0.4 \%, \mathrm{w} / \mathrm{v})$ and ampicillin $\left(100 \mu \mathrm{g} \mathrm{m}^{-1}\right)$. Three colonies that were surrounded by clear zones and were resistant to ampicillin were isolated.

Recombinant DNA procedures. Restriction endonucleases were obtained from several sources (Amersham, Boehringer Mannheim, New England Biolabs and Promega) and were used as specified by the manufacturers. The enzymes exonuclease III and S1 nuclease were obtained from Boehringer Mannheim. $\alpha^{3}{ }^{32} \mathrm{P}$ - and $\alpha^{{ }^{35}}$ S-labelled nucleotides were obtained from Amersham

Plasmid DNA was prepared by the alkaline-hydrolysis method of Ish-Horowicz \& Burke (1981). C. acetobutylicum chromosomal DNA was prepared by the method of Marmur (1961), which was modified (Zappe et al., 1986) to overcome the high nuclease activity exhibited by $C$. acetobutylicum (Urano et al., 1983).

For exonuclease III digestion, the $C$. acetobutylicum insert-DNA from pMET7C was subcloned into the PstI site of the phagemid Bluescript KS (Stratagene). Progressive deletions of this clone from both the $5^{\prime}$ and the $3^{\prime}$ ends of the insert were generated by unidirectionally digesting XhoI-ApaI and BamHI-SacI fragments with exonuclease III (Henikoff, 1984), respectively. The deletions were transformed into $E$. coli JM105 and transformants were selected on LB agar containing $100 \mu \mathrm{g}$ ampicillin $\mathrm{ml}^{-1}$, giving plasmids pCar4-8 (Fig. 1).

Nucleotide sequencing. The nucleotide sequence of both strands of pCar 5 containing the metronidazole-active region was determined using overlapping DNA fragments generated by exonuclease III digestion as described above. Nucleotide sequencing was carried out by the dideoxy chain-termination method (Sanger et al., 1977), according to the protocol outlined by Tabor \& Richardson (1987), using the Sequenase DNA sequencing kit (USB). The DNA chains were radiolabelled with $\left.{ }^{35} \mathrm{~S}\right] \mathrm{dATP} \alpha \mathrm{S}\left(1200 \mathrm{Ci} \mathrm{mmol}^{-1}, 44 \cdot 4 \mathrm{TBq} \mathrm{mmol}^{-1}\right.$; Amersham). The nucleotide and deduced amino acid sequences were analysed on a VAX 6000-330 computer using the GCG suite of sequence analysis programs (Devereux et al., 1984).

Metronidazole sensitivity. An overnight culture of E. coli F19 was diluted $10^{-4}$ with sterile water, and $100 \mu \mathrm{l}$ was spread onto pre-reduced LB agar supplemented with $0.2 \% \mathrm{NaNO}_{3}, 0 \cdot 1 \%$ glucose and various concentrations of metronidazole (Sigma). The plates were incubated anaerobically. The MIC was taken to be the amount of metronidazole per $\mathrm{ml}$ that totally inhibited growth.

Enzyme assays. Amylase activity from the culture supernatant of $B$. subtilis cells grown in liquid culture was determined by measuring the increase in reducing sugars released from starch by the 3,5-dinitrosalicyclic acid method of Miller (1959) as previously described by Rumbak et al. (1991). Amylase activities

Table 1. Bacterial strains

\begin{tabular}{|c|c|c|}
\hline Strain & Relevant characteristics & Reference/source \\
\hline \multicolumn{3}{|c|}{ C. acetobutylicum } \\
\hline P262 & Wild-type & Laboratory stock \\
\hline 8052 & Wild-type & NCIMB \\
\hline \multicolumn{3}{|l|}{ E. coli } \\
\hline $\mathrm{DH} 5 \alpha$ & $\begin{array}{l}\sup E 44 \Delta \text { lac } U 169 \text { ( } \phi 80 \text { lac } Z \Delta \mathrm{M} 15) \text { bsdR } 17 \\
\operatorname{rec} A 1 \text { end } A 1 \text { gyr } A 96 \text { thi-1 } \operatorname{rec} A 1\end{array}$ & Hanahan (1983) \\
\hline GD40 & supH leu & Leclerc et al. (1990) \\
\hline F19 & Nitroreductase-deficient & Santangelo et al. (1991) \\
\hline JM105 & end $A$ bsd $\mathrm{R} \sup E \operatorname{sbc} B$ thi1 $\operatorname{str} A \Delta(l a c-p r o A B) \lambda$ & Yanisch-Perron et al. (1985) \\
\hline CGSC 808 & lac122 $\lambda^{-}$relA1 spoT1 thi-1 & Pardee et al. (1959) \\
\hline CGSC 5674 & leuB6 thi-1 lacY1 galR61 str A129 $\lambda^{-}$supE44 & Buttin (1963) \\
\hline CGSC 5060 & lacZ2286(Am) purR97 rpsL150 relA1 spoT1 $\lambda^{-}$ & Kilstrup et al. (1989) \\
\hline \multicolumn{3}{|l|}{ B. subtilis } \\
\hline 168 & $\operatorname{trp} C 2$ & Henkin et al. (1991) \\
\hline WLN-29 & aroG932 trpC2 ccpA::Tn917lac & Henkin et al. (1991) \\
\hline ZB307A & $\mathrm{sp} \beta c 2$ del2:: $\operatorname{Tn} 917:: \mathrm{pSK} 10 \Delta 6$ & Zuber et al. (1987) \\
\hline ZB449 & $\operatorname{trp} C 2$ phe $A 1$ abrB703 SP $\beta$ cured & Zuber et al. (1987) \\
\hline
\end{tabular}


were expressed as $\mu \mathrm{mol}$ reducing sugar produced per min per OD unit. Amylase production by $B$. subtilis on agar was tested by plating on brain heart infusion agar (BHIA) containing $1 \%$ $(\mathrm{w} / \mathrm{v})$ potato starch; glucose-resistant amylase production was tested by the addition of $2 \%(\mathrm{w} / \mathrm{v})$ glucose. After overnight incubation, plates were flooded with a solution of $0 \cdot 5 \% \mathrm{I}_{2} / 5 \cdot 0 \%$ $(\mathrm{w} / \mathrm{v}) \mathrm{KI}$ for detection of starch hydrolysis. Starch-degrading activity by $E$. coli cells containing recombinant plasmids was tested by plating on LB agar containing starch-azure and ampicillin. The degradation and solubilization of starch by $E$. coli cells was assayed in LB medium containing $1 \%$ insoluble starch (Unilab). Samples $(8 \mathrm{ml})$ were removed at different time intervals and centrifuged at $4000 \mathrm{~g}$ for $5 \mathrm{~min}$ and the remaining insoluble starch was measured by wet weight.

Complementation studies. $B$. subtilis WLN-29 has a transposon mutation in the catabolite control protein gene $(c p A)$ which results in the loss of the glucose repression of amylase synthesis (Henkin et al., 1991). The ability of the $C$. acetobutylicum reg $A$ gene to complement the $B$. subtilis $\operatorname{ccp} A$ mutation was determined by insertion of $\operatorname{reg} A$ into an $\mathrm{SP} \beta$-specialized transducing phage vector, and integration into the chromosome of strain WLN-29 (Zuber \& Losick, 1987).

The effect of the $C$. acetobutylicum reg $A$ gene on the regulation of acetolactate synthase activity and acetoin production was determined in B. subtilis WLN-29. Acetoin was assayed qualitatively by the Voges-Proskauer reaction (Conn et al., 1957).

Complementation of repression of purine nucleotide synthesis in E. coli utilized the method of Kilstrup et al. (1989), in a selection based on repression of cytosine deaminase synthesis. Complementation for galactokinase repression in E. coli was performed using the method of Wilson \& Hogness (1966). Complementation for $\beta$-galactosidase repression was performed using the method of Sambrook et al. (1989). Complementation of an E. coli supH mutant involved growing the supH strain, with or without the $\operatorname{reg} A$ gene, on minimal medium with or without leucine (Leclerc et al., 1990).

\section{RESULTS}

\section{Plasmid PMET7C and metronidazole sensitivity}

Plasmid pMET7C containing a $6.05 \mathrm{~kb}$ insert of $C$. acetobutylicum DNA, was isolated in $E$. coli F19 by screening for transformants sensitive to $20 \mu \mathrm{g}$ metronidazole $\mathrm{ml}^{-1}$ (Santangelo et al., 1991). pMET7C cells overproduced a $100 \mathrm{kDa}$ protein which was easily observed on SDS-polyacrylamide gels, and was further characterized to determine the role that this large protein might play in metronidazole sensitivity. Exonuclease III shortenings of PMET7C indicated that the large protein and the metronidazole sensitivity were determined by different regions of the $6.05 \mathrm{~kb}$ insert DNA on pMET7C (Fig. 1). The metronidazole sensitivity region was localized on a $2.6 \mathrm{~kb}$ derivative of pMET7C (pCar5). Sequencing of this subclone revealed a truncated ORF of 892 bp (bases 278-1169; Fig. 2). Colony hybridization, using pMET7C as a probe, was used to isolate a $6.5 \mathrm{~kb}$ clone from $C$. acetobutylicum $\mathrm{pEcoR} 251$ plasmid-pools constructed by Zappe et al. (1986). This newly isolated recombinant plasmid contained the entire ORF of the gene coding for metronidazole sensitivity and was named pCar1 (summarized in Fig. 1).

\section{Nucleotide sequence of the $C$. acetobutylicum gene conferring metronidazole sensitivity}

The nucleotide sequence of the region of $C$. acetobutylicum DNA conferring metronidazole sensitivity in E. coli F19 revealed a complete ORF of $972 \mathrm{bp}, \operatorname{reg} A$, which encoded a protein of 324 amino acids with a calculated $M_{\mathrm{r}}$ of 35600 (Fig. 2). The ATG start codon was preceded by a ribosome-binding site (GGAGGA) 8 bp upstream. This Shine-Dalgarno sequence resembles that reported for the Staphylococcus aureus $\beta$-lactamase (Mclaughlin et al., 1981) and the $C$. acetobutylicum endoglucanase gene (Zappe et al., 1988). A putative promoter region showing extensive homology to the Gram-positive promoters regulating the C. acetobutylicum $g \ln A$ gene was detected at nucleotide positions 212-217 and 237-242 (Fig. 2) (Janssen et al., 1990). Another relevant feature in the DNA sequence was the presence of two stem-loop structures downstream of the $\operatorname{reg} A$ gene. This dyad symmetry region is indicative of factor-independent terminators (Brendel \& Trifonov, 1984). Just downstream from the first of these regions is a stretch of eight consecutive thymine residues. The dyad symmetry allows for the formation of stable hairpin structures in the RNA transcript, and has been implicated in slowing down the polymerase, whereas the thyminerich region allows for the formation of an $\mathrm{rU}-\mathrm{dA}$ hybrid that facilitates release of the transcript (Martin \& Tinoco, 1980). Partial DNA sequencing of ORF2, which lies upstream of the $\operatorname{reg} A$ gene and encodes the $100 \mathrm{kDa}$ protein on the pMET7C, indicated that it has homology to a tRNA synthetase.

Sequence comparisons at the amino acid level suggested that the deduced protein encoded by the $\operatorname{reg} A$ gene was a DNA-binding protein (Fig. 3). The deduced amino acid sequence encoded by reg $A$ showed $40 \%$ identity to the $B$. subtilis $\operatorname{ccp} A$ gene product, and $38 \%$ identity to the $B$. megaterium ccp $A$ gene product (Fig. 3). The RegA protein also showed considerable homology to PurR ( $34 \%$ amino acid identity), LacI ( $24 \%$ identity) and Shl, a tRNA repressor from E. coli ( $21 \%$ identity). The amino terminal region of the RegA protein contained an amino acid sequence which has been shown to form a helixturn-helix structure and was very similar to the DNAbinding domains of other repressor proteins (Fig. 3) (Adler et al., 1972; Sauer et al., 1982).

\section{Complementation of $E$. coli regulatory mutants}

E. coli $\operatorname{supH}$ is a supressor mutation that relieves the auxotrophies associated with the presence of leu and ilv mutations. However, when E. coli contains the shl gene (suppressor $\mathrm{H}$-linked phenotype) on a multicopy plasmid, the growth of supH cells is prevented on minimal medium (Leclerc et al., 1990) while there is no inhibition of growth of an $E$. coli wild-type host. Since the $C$. acetobutylicum $\operatorname{reg} A$ gene product showed homology to the $E$. coli shl gene product, the ability of the $\operatorname{reg} A$ gene to complement the $s b l$ gene was determined. Transformation of the E. coli GD40 leu supH mutant with pCar1 containing the $C$. acetobutylicum $\operatorname{reg} A$ gene resulted in the inability of the $E$. 


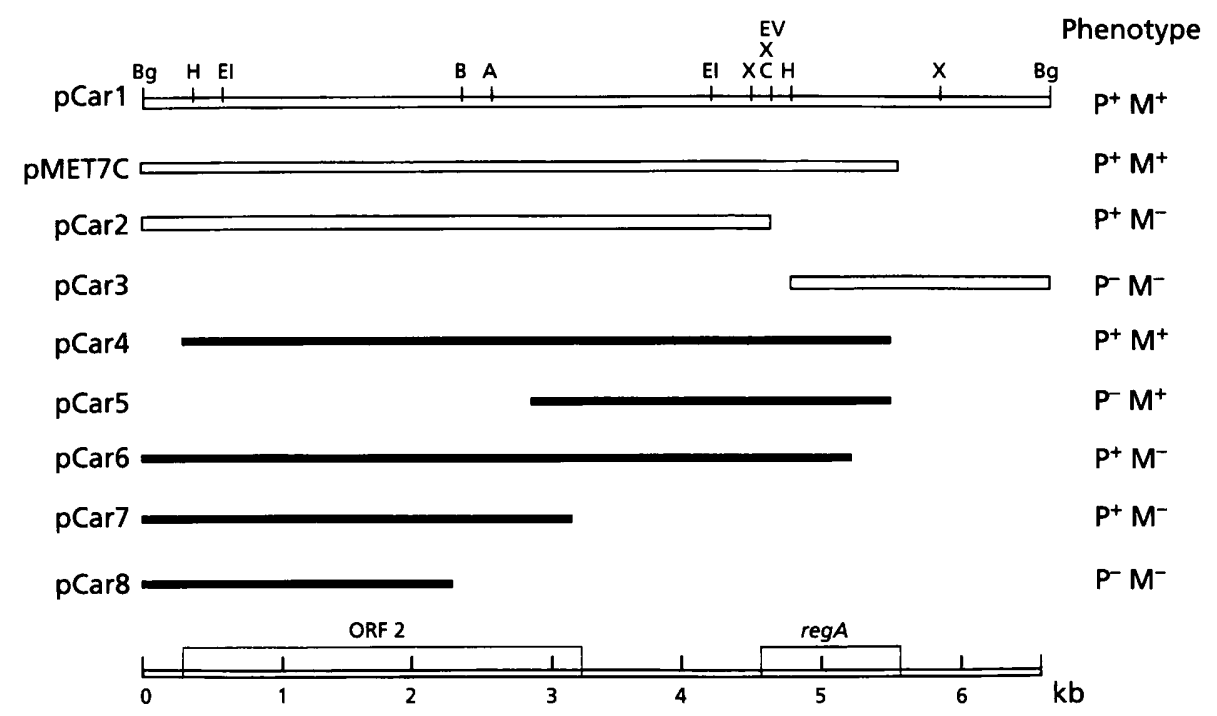

Fig. 1. Restriction map of $C$. acetobutylicum DNA cloned in pCar1. The $C$. acetobutylicum DNA in pMET7C originally isolated by Santangelo et al. (1991) was cloned in the vector pEcoR251 (Zabeau \& Stanley, 1982). The vector in plasmids pCar1, pCar2 and pCar3 is the integrative shuttle vector, pDH88 (Henner, 1990). Plasmids pCar4-8 are deletions of the $B g / I I-S a u 3 A$ insert DNA subcloned in Bluescript SK. The metronidazole-sensitive phenotypes conferred on $E$. coli by the various constructs are indicated by $M+$ or $M-$. The $100 \mathrm{kDa}$ protein expressed in $E$. coli by the various constructs and determined by SDS-PAGE are indicated by $\mathrm{P}^{+}$or $\mathrm{P}^{-}$. A, Accl; $\mathrm{B}, \mathrm{BamHI} ; \mathrm{Bg}, \mathrm{Bg} / \mathrm{ll} ; \mathrm{C}, \mathrm{Clal}$; El, EcoRI; EV, EcoRV; H, HindlII; $\mathrm{P}$, Pstl; X, Xbal.

coli GD40 leu supH mutant to grow on minimal medium without leucine. The addition of leucine $\left(100 \mu \mathrm{g} \mathrm{ml}^{-1}\right)$ to the minimal medium enabled the $E$. coli GD40 leu supH (pCar1) transformant to grow. The $C$. acetobutylicum reg $A$ gene was unable to complement the lacI, galR or purR mutations in the various $E$. coli strains.

\section{Complementation of the B. subtilis ccpA gene}

The $B$. subtilis WLN-29 $\operatorname{ccp} A$ mutant is unable to mediate glucose repression of amylase synthesis (Henkin et al., 1991). Since the $C$. acetobutylicum $\operatorname{reg} A$ gene product showed the highest amino acid homology to the $\operatorname{ccp} A$ gene product, the ability of the $\operatorname{reg} A$ gene to complement cсp $A$ was determined. The $C$. acetobutylicum $\operatorname{reg} A$ gene, within a $6.5 \mathrm{~kb}$ DNA fragment, was inserted into a SP $\beta$ specialized transducing phage vector, and transduced into the $B$. subtilis $\operatorname{csp} A$ mutant. Plasmids $\mathrm{pCar} 2$ and $\mathrm{pCar} 3$ containing the DNA regions flanking the $\operatorname{reg} A$ ORF were transduced into the $B$. subtilis $c c p A$ mutant as controls. Transductants were selected for chloramphenicol resistance conferred by the transducing phages and tested for production of amylase on BHIA medium containing $1 \%$ $(\mathrm{w} / \mathrm{v})$ starch with or without $2 \%(\mathrm{w} / \mathrm{v})$ glucose. After flooding of the plates with iodine solution, colonies of the wild-type $B$. subtilis 168 control strain were surrounded by clear zones on the starch plates without glucose, but the production of amylase was repressed on the starch plates with glucose and no clear zones were observed. The $B$. subtilis c c $A$ mutant colonies were surrounded by clear zones on the starch media with or without glucose. $B$. subtilis $\operatorname{ccp} A \operatorname{reg} A$ transductants exhibited repression of amylase activity in the presence or absence of glucose, and zones surrounding the colonies on starch plates with or without glucose were not observed. $B$. subtilis $\operatorname{ccp} A$, car2 and $\operatorname{car} 3$ transductants exhibited no glucose repression, and colonies were surrounded by clear zones on starch medium with or without glucose.

The transductants were tested for the production of amylase activity in liquid $\mathrm{BHI}$ medium containing $1 \%$ starch (Table 2). The two transductants containing an incomplete $\operatorname{reg} A$ gene, $\mathrm{pCar} 2$ and $\mathrm{pCar} 3$, produced levels of amylase activity similar to that of the $B$. subtilis $\operatorname{ccp} A$ mutant, that is 59,50 and $58 \mathrm{U}$ amylase activity, respectively. The transductant with the intact $\operatorname{reg} A$ gene, pCar1, showed marked repression of amylase activity and only produced $9 \mathrm{U}$ amylase activity. The $C$. acetobutylicum $\operatorname{reg} A$ gene therefore appears to complement the $B$. subtilis $\operatorname{ccp} A$ gene, but its repressive activity is not relieved in the absence of glucose.

\section{Effect of the $C$. acetobutylicum regA gene on acetoin production in B. subtilis}

The $c c p A$ gene in $B$. subtilis also controls the production of acetoin in the presence of glucose by regulating the expression of the als $A$ gene responsible for the synthesis of acetolactate synthase. The $B$. subtilis 168 wild-type strain produced acetoin in LB medium in the presence of $2 \%$ glucose (Table 2). The $B$. subtilis $\operatorname{ccp} A$ mutant produced acetoin in $\mathrm{LB}+2 \%$ glycerol medium (data not shown), although it did not produce acetoin in either LB or LB + glucose medium. Transduction of the B. subtilis 


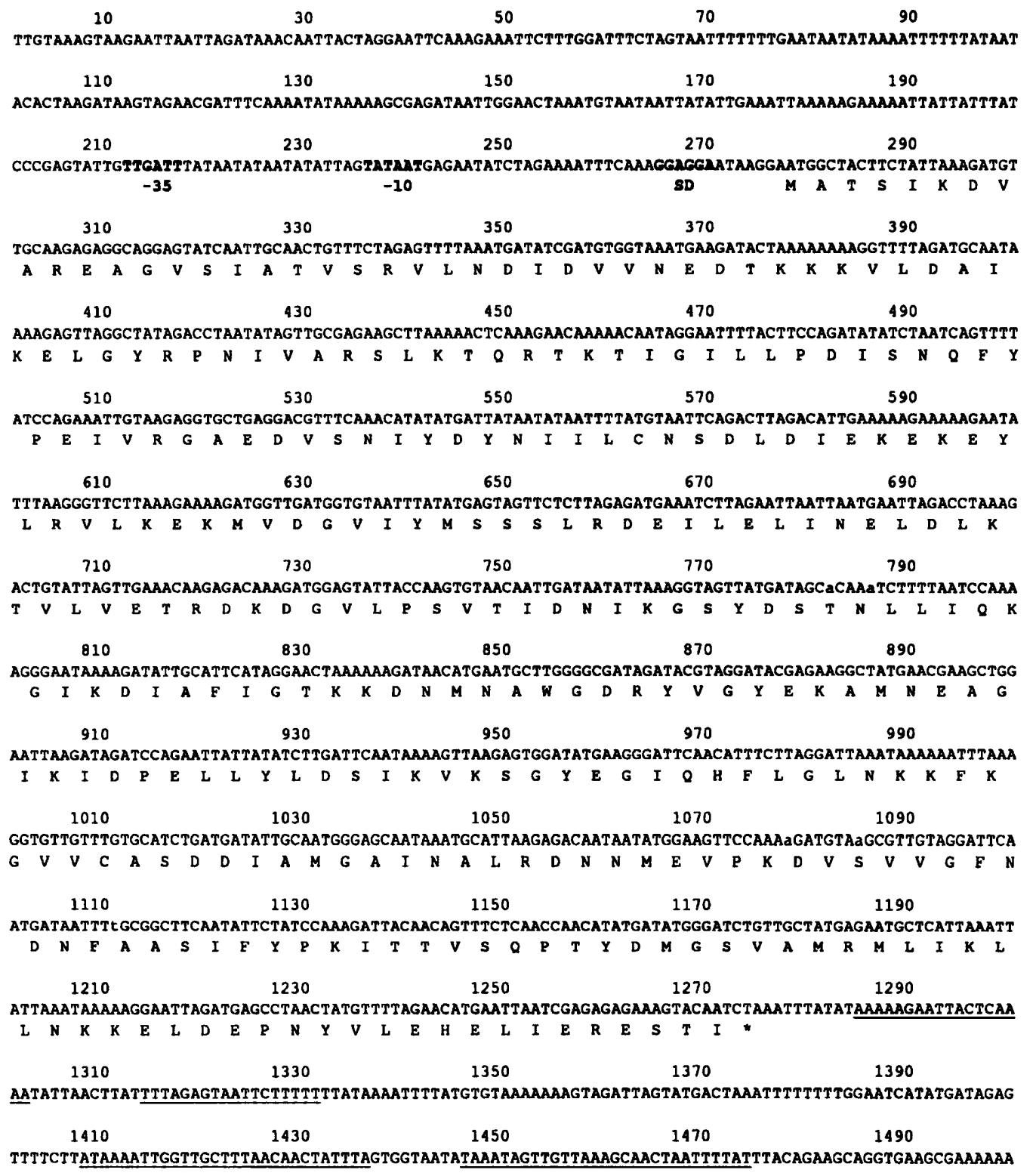

Fig. 2. Nucleotide sequence of the DNA fragment containing the 972 bp regA ORF. The nucleotide sequence is numbered throughout. The deduced amino acid sequence of the repressor is shown in single-letter code below the coding sequence. The putative promoter sequences $(-35$ and -10$)$ and Shine-Dalgarno sequence (SD) are shown in bold type. Dyad symmetries are indicated by horizontal lines.

$\operatorname{csp} A$ mutant with the recombinant $\mathrm{SP} \beta$ phage containing the intact $C$. acetobutylicum $\operatorname{reg} A$ gene restored the ability to produce acetoin in the LB + glucose medium, but both the transductants with the truncated $\operatorname{reg} A$ genes (Table 2) were unable to produce acetoin.

\section{Cloning of C. acetobutylicum starch-degrading enzyme genes}

Since the $\operatorname{reg} A$ gene from $C$. acetobutylicum $\mathrm{P} 262$ complemented a $B$. subtilis $\operatorname{ccp} A$ mutant, the ability of the $\operatorname{reg} A$ gene to regulate the expression of a $C$. acetobutylicum gene was investigated. A C. acetobutylicum P262 gene bank was screened extensively in E. coli JM105 for the presence of an amylase-type gene, but no amylase gene was detected by this method. In contrast, the screening of a similar gene bank containing $C$. acetobutylicum NCIMB 8052 DNA yielded three $E$. coli JM105 transformants which were ampicillin-resistant and surrounded by clear zones on blue starch-azure agar plates. E. coli JM105 colonies containing an ampicillin-resistant control plasmid did not produce clear zones on the starch-azure agar containing ampicillin. One of the recombinant plasmids pEco106 was chosen for further study and was characterized by restriction endonuclease mapping and contained a $8.5 \mathrm{~kb}$ insert of $C$. acetobutylicum DNA. 


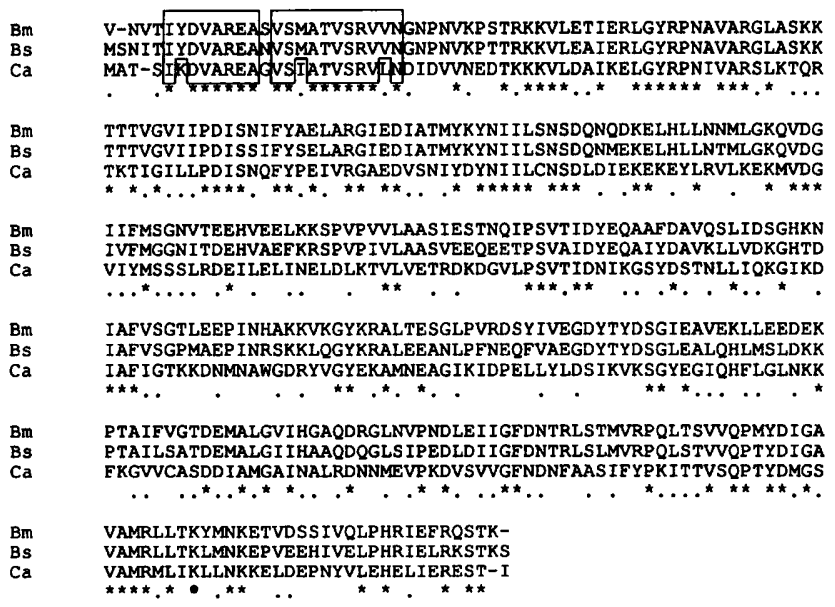

Fig. 3. Multiple sequence alignment of the $C$. acetobutylicum repressor ( $\mathrm{Ca})$, the $B$. subtilis catabolite control protein (Bs), and the $B$. megaterium catabolite control protein $(\mathrm{Bm})$. The consensus sequence is displayed below the alignment, with identical amino acids indicated by asterisks, and similar residues by dots. The helix-turn-helix DNA-binding domains of these repressor proteins are boxed.

\section{Regulation of starch-degrading activity by pEco106}

The ability of the $C$. acetobutylicum $\operatorname{reg} A$ gene to affect the production of starch-degrading activity encoded by pEco106 was determined. The starch-degrading region from pEco106 was contained on a $10.7 \mathrm{~kb} \mathrm{BamHI-}$ HindIII fragment; this fragment was subcloned into pACYC184 to give plasmid pACYCStar1, which was compatible with pCar1. Starch-degrading activity was determined in E. coli DH5 $\alpha$ cells containing pACYCStar1, both pACYCStar1 and pCar1, or both pACYC and Bluescript SK. E. coli DH5 $\alpha$ (pACYCStar1) colonies were surrounded by clear zones on starch-azure agar plates. However, no zones were observed surrounding E. coli DH5 $\alpha$ (pACYCStar1 plus pCar1) colonies or the control $E$. coli. The presence of the $\operatorname{reg} A$ gene in $E$. coli cells containing the $C$. acetobutylicum starch-degrading region

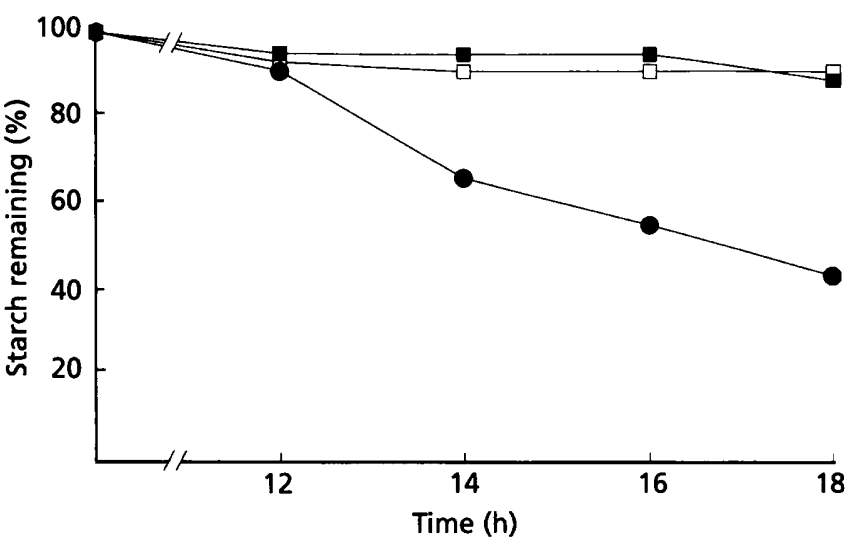

Fig. 4. Starch hydrolysis in overnight cultures of $E$. coli DH5 $\alpha$ (pACYCStar1) (O), E. coli DH5 $\alpha$ (pACYCStar1)(pCar1) (U) and $E$. coli DH5 $\alpha(\mathrm{pACYC184})(B$ luescript SK) ( $\square$ ). The $100 \%$ value represents $2.5 \mathrm{~g}$ insoluble starch in $8 \mathrm{ml}$ medium.

clearly repressed starch-degradation activity in liquid medium (Fig. 4).

\section{DISCUSSION}

The initial aim of this study was to identify $C$. acetobutylicum electron transport genes which reductively activate metronidazole. In a previous study, we reported the isolation of 25 clones which rendered E. coli F19 sensitive to metronidazole (Santangelo et al., 1991). One of these clones, pMET7C, was chosen for further study since it produced a $100 \mathrm{kDa}$ protein in E. coli $\mathrm{F} 19$ cells. Subcloning of the $C$. acetobutylicum DNA on pMET7C indicated that the $100 \mathrm{kDa}$ protein was not involved in the metronidazole sensitivity of $E$. coli transformants, but that a second gene on pMET7C rendered E. coli F19 sensitive to metronidazole. Surprisingly, the $C$. acetobutylicum gene product responsible for metronidazole sensitivity in $E$. coli F19 did not share any properties or amino acid homology with proteins associated with electron transport or with enzymes capable of carrying out reduction

Table 2. Acetoin production and extracellular amylase activity in B. subtilis strains

\begin{tabular}{|llccc|}
\hline \multirow{2}{*}{ Strain } & \multicolumn{1}{c}{ Genotype } & \multicolumn{2}{c|}{ Acetoin production } & \multirow{2}{*}{ Amylase activity } \\
\cline { 3 - 4 } & & No addition & Glucose & \\
\hline ZB449 & Wild-type & - & + & 26 \\
WLN-29 & $c c p A:: T n$ 17 & - & - & 58 \\
WLN-29 & $c c p A:: T n 917 / \mathrm{SP} \beta$-pCar1 & - & + & 9 \\
WLN-29 & $c c p A:: T n 917 / \mathrm{SP} \beta$-pCar2 & - & - & 59 \\
WLN-29 & ccp $A:: T n$ T17/SP $\beta$-pCar3 & - & - & 50 \\
\hline
\end{tabular}

Amylase activity was assayed by measuring the increase in reducing sugars produced from starch ( $\mu \mathrm{mol}$ per min per OD unit) by the 3,5-dinitrosalicyclic method. Acetoin production was assayed by the Voges-Proskauer reaction. 
reactions. Homology studies indicated that the $C$. acetobutylicum gene controlling metronidazole sensitivity encoded a repressor protein that was similar to the LacI family of repressor proteins. The $C$. acetobutylicum gene, which was termed $\operatorname{reg} A$, appears to be the first repressor protein of this type from $C$. acetobutylicum to be reported. The conserved amino acid residues associated with the LacI-type DNA-binding region were present in the amino-terminal portion of the predicted amino acid sequence of the $\operatorname{reg} A$ gene.

The complementation of the supH mutation in $E$. coli $\mathrm{Leu}^{-}$strains by the $C$. acetobutylicum $\mathrm{reg} A$ gene provides a mechanism for the control of metronidazole sensitivity by the $C$. acetobutylicum reg $A$ repressor protein in E. coli. It has been shown that a supH mutation renders $E$. coli sensitive to UV irradiation and high temperatures. It appears that a $\operatorname{supH}$ mutant is therefore unable to produce a DNA-repair protein, unless the $s h l$ repressor is present (Leclerc et al., 1989). We propose that the $C$. acetobutylicum RegA protein fortuitously functions as a repressor of the supH mutation in an analogous fashion to the Shl repressor protein. It has been demonstrated that $E$. coli strains which are unable to produce a fully functional complement of DNA-repair proteins show increased sensitivity to metronidazole (Jackson et al., 1984; Yeung et al., 1984). By indirectly inhibiting the production of a UV-repair protein, the presence of $\operatorname{reg} A$ renders $E$. coli F19 sensitive to metronidazole.

The deduced amino acid sequence of the $C$. acetobutylicum $\operatorname{reg} A$ gene showed the highest homology to the $B$. subtilis and $B$. megaterium $C \mathrm{cp} A$ proteins, which act as negative regulators controlling amylase production by the amy $E$ genes in response to glucose. Transductants containing the intact $\operatorname{reg} A$ gene on pCar1 were able to complement a B. subtilis ccp $A$ mutant, and showed repression of amylase activity in the presence or absence of glucose. Transductants containing truncated versions of $\operatorname{reg} A$ on pCar2 or pCar3 were unable to repress amylase activity, irrespective of the presence or absence of glucose, indicating that the flanking regions of the $\operatorname{reg} A$ gene $\operatorname{did}$ not contain additional genes which affected the production of amylase by the $B$. subtilis $c c p A$ mutant, and that the intact $\operatorname{reg} A$ gene was required for the repression of amylase activity. The other phenotype associated with the $B$. subtilis $\operatorname{ccp} A$ gene, regulation of acetolactate synthase expression, was complemented by the $C$. acetobutylicum $\operatorname{reg} A$ gene in liquid medium. It is concluded that the $C$. acetobutylicum $\operatorname{reg} A$ gene is able to complement the $B$. subtilis $\operatorname{ccp} A$ mutation, albeit somewhat differently in the case of glucose repression of amylase synthesis.

The complementation of the $B$. subtilis $\operatorname{ccp} A$ mutant by the $C$. acetobutylicum $\operatorname{reg} A$ gene suggested that it may be involved in the regulation of starch degradation in $C$. acetobutylicum. Experiments carried out in E. coli DH5a transformed with two plasmids, pCar1 containing the $\operatorname{reg} A$ gene, and $\mathrm{pStar1}$, containing an uncharacterized $C$. acetobutylicum gene capable of degrading and solublizing starch, showed that the RegA protein repressed the degradation of starch. Further experiments are under way to elucidate the specific role of this starch-degrading enzyme in $C$. acetobutylicum.

It is interesting that in $B$. subtilis it has recently been reported that CcpA is involved in the regulation of the acetate kinase gene (Grundy et al., 1993). Acetate kinase is part of a pathway for the interconversion of acetyl-CoA and acetate. In this pathway, acetyl-CoA is initially converted to an acetyl phosphate intermediate by phosphotransacetylase, and then converted to acetate by acetate kinase. Since this biochemical pathway has a critical role in the physiology of $C$. acetobutylicum (Jones \& Woods, 1986), it will be important to establish whether $\operatorname{Reg} \mathrm{A}$ is involved in the regulation of acetate production as well as the utilization of carbohydrate substrates.

\section{ACKNOWLEDGEMENTS}

We thank Di James for excellent technical assistance, and acknowledge research grants from National Chemical Products and the Foundation for Reseach Development.

\section{REFERENCES}

Adler, K., Beyreuther, K., Fanning, E., Geisler, N., Gronenborn, B., Klemm, A., Muller-Hill, B., Pfahl, M. \& Schmitz, A. (1972). How lac repressor binds to DNA. Nature 237, 322-327.

Allcock, E. R., Reid, S. J., Jones, D. T. \& Woods, D. R. (1982). Clostridium acetobutylicum protoplast formation and regeneration. Appl Environ Microbiol 43, 719-721.

Annous, B. A. \& Blaschek, H. P. (1990). Regulation and localization of amylolytic enzymes in Clostridium acetobutylicum A TCC 824. Appl Environ Microbiol 56, 2559-2561.

Bahl, H. \& Gottschalk, G. (1988). Microbial production of butanol/acetone. In Biotechnology, pp. 1-30. Edited by J. Rehm \& G. Reed. Weinheim: VCH Verlagsgesellschaft.

Brendel, V. \& Trifonov, E. N. (1984). A computer algorithm for testing potential prokaryote terminators. Nucleic Acids Res 12, $4411-4427$.

Buttin, G. (1963). Mécanismes régulateurs dans la biosynthèse des enzymes du métabolisme du galactose chez Eschericbia coli. II. Le déterminisme génétique de la regulation. J Mol Biol 7, 183-205.

Clark, D. \& Cronan, J. E., Jr (1980). Escherichia coli mutants with altered control of alcohol dehydrogenase and nitrate reductase. J Bacteriol 141, 177-183.

Conn, H. J., Jennison, M. W. \& Weiss, O. B. (1957). Routine tests for the identification of bacteria. In Manual of Microbiological Metbods, pp. 140-168. Edited by the Committee on Bacteriological Technique of the Society of American Bacteriologists. New York: McGraw-Hill.

Devereux, J., Haeberli, P. \& Smithies, O. (1984). A comprehensive set of sequence analysis programs for the VAX. Nucleic Acids Res 12, 387-395.

Grundy, F. J., Waters, D. A., Allen, S. H. G. \& Henkin, T. M. (1993). Regulation of the Bacillus subtilis acetate kinase gene by CcpA. $J$ Bacteriol 175, 7348-7355.

Hanahan, D. (1983). Studies on transformation of Escherichia coli with plasmids. $J$ Mol Biol 166, 557-580.

Henikoff, S. (1984). Unidirectional digestion with exonuclease III creates targeted breakpoints for DNA sequencing. Gene 28, 351-359. 
Henkin, T. M., Grundy, F. J., Nicholson, W. L. \& Chambliss, G. H. (1991). Catabolite repression of amylase gene expression in Bacillus subtilis involves a trans-acting gene product homologous to the Escherichia coli lacI and galR repressors. Mol Microbiol 5, 575-584.

Henner, D. J. (1990). Inducible expression of regulatory genes in Bacillus subtilis. Metbods Enzymol 185, 223-228.

Ish-Horowicz, D. \& Burke, J. F. (1981). Rapid and efficient cosmid cloning. Nucleic Acids Res 9, 2989-2998.

Jackson, D., Salem, A. \& Coombs, G. H. (1984). The in vitro activity of metronidazole against strains of Escherichia coli with impaired DNA repair systems. I Antimicrob Chemother 13, 227-236.

Janssen, P. J., Jones, D. T. \& Woods, D. R. (1990). Studies on Clostridium acetobutylicum gln $A$ promoters and antisense RNA. Mol Microbiol 4, 1575-1583.

Jones, D. T. \& Woods, D. R. (1986). Acetone and butanol revisited. Microbiol Rev 50, 484-524.

Jones, D. T. \& Woods, D. R. (1989). Solvent production. In Biotecbnology Handbooks, vol. 3, Clostridia, pp. 105-144. Edited by N. P. Minton \& D. J. Clarke. New York: Plenum Press.

Jones, D. T., van der Westhuizen, A., Long, S., Allcock, E. R., Reid, S. J. \& Woods, D. R. (1982). Solvent production and morphological changes in Clostridium acetobutylicum. Appl Environ Microbiol 43, 1434-1439.

Kilstrup, M., Meng, L. M., Neuhard, J. \& Nygaard, P. (1989). Genetic evidence for the repressor of synthesis of cytosine deaminase and purine biosynthesis enzymes in Escherichia coli. J Bacteriol 171, 2124-2127.

Leclerc, G., Sirard, C. \& Drapeau, G. R. (1989). The Escherichia coli cell division mutation fts MI is in serU. J Bacteriol 171, 2090-2095.

Leclerc, G., Noel, G. \& Drapeau, G. R. (1990). Molecular cloning, nucleotide sequence, and expression of $s h l$, a new gene in the 2minute region of the genetic map of Escherichia coli. J Bacteriol 172, 4696-4700.

Long S., Jones, D. T. \& Woods, D. R. (1984a). Initiation of solvent production, clostridial stage and endospore formation in Clostridium acetobutylicum P262. Appl Microbiol Biotechnol 20, 256-261.

Long S., Jones, D. T. \& Woods, D. R. (1984b). The relationship between sporulation and solvent production in Clostridium acetobutylicum P262. Biotechnol Lett 6, 529-534

Mclaughlin, J. R., Murray, C. L. \& Rabinowitz, J. C. (1981). Unique feature in the ribosome binding site sequence of the gram-positive Staphylococcus aureus $\beta$-lactamase gene. J Biol Chem 256, 11283-11291.

Marmur, J. (1961). A procedure for the isolation of deoxyribonucleic acid from microorganisms. J Mol Biol 3, 208-218.

Martin, F. H. \& Tinoco, I. Jr (1980). DNA-RNA hybrid duplexes containing oligo $(\mathrm{dA}: \mathrm{rU})$ sequences are exceptionally unstable and may facilitate termination of transcription. Nucleic Acids Res 8, 2295-2299.

Miller, G. L. (1959). Use of dinitrosalicylic acid reagent for determination of reducing sugars. Anal Cbem 31, 426-428.

O'Brien, R. W. \& Morris, J. G. (1971). Oxygen and the growth and metabolism of Clostridium acetobutylicum. J Gen Microbiol 68, 307-318.
Pardee, A. B., Jacob, F. \& Monod, J. (1959). The genetic control and cytoplasmic expression of 'inducibility' in the synthesis of $\beta$ galactosidase by Escherichia coli. J Mol Biol 1, 165-178.

Rogers, P. (1984). Genetics and biochemistry of Clostridium relevant to development of fermentation processes. Appl Microbiol 31, 1-60. Rumbak, E., Rawlings, D., Lindsey, G. G. \& Woods, D. R. (1991). Cloning, nucleotide sequence, and enzymatic characterization of an amylase from the ruminal bacterium Butyrivibrio fibrisolvens $\mathrm{H} 17 \mathrm{c}$. $J$ Bacteriol 173, 4203-4211.

Sambrook, J., Fritsch, E. F. \& Maniatis, T. (1989). Molecular Cloning: a Laboratory Manual, 2nd edn. Cold Spring Harbor, NY: Cold Spring Harbor Laboratory.

Sanger, F., Nicklen, S. \& Coulson, A. R. (1977). DNA sequencing with chain-terminating inhibitors. Proc Natl Acad Sci US A 74, 5463-5467.

Santangelo, J. D., Jones, D. T. \& Woods, D. R. (1991). Metronidazole activation and the isolation of Clostridium acetobutylicum electron transport genes. J Bacteriol 173, 1088-1095.

Sauer, R. T., Yocum, R. R., Doolittle, R. F., Lewis, M. \& Pabo, C. O. (1982). Homology among DNA-binding proteins suggests use of a conserved super-secondary structure. Nature 298, 447-451.

Tabor, S. \& Richardson, C. C. (1987). DNA sequence analysis with a modified bacteriophage T7 DNA polymerase. Proc Natl Acad Sci US A 84, 4767-4771.

Urano, N., Karube, I., Suzuki, S., Yamada, T., Hirochika, H. \& Sakaguchi, K. (1983). Isolation and partial characterization of large plasmids in hydrogen-evolving bacterium Clostridium acetobutylicum. Eur J Appl Microbiol Biotechnol 17, 349-354.

Wilson, D. B. \& Hogness, D. S. (1966). Galactokinase and uridine diphosphogalactose 4-epimerase from Escherichia coli. Methods Enzymol 8, 229-240.

Yanisch-Perron, C., Vieira, J. \& Messing, J. (1985). Improved M13 phage cloning vectors and host strains: nucleotide sequences of M13mp8 and pUC19 vectors. Gene 33, 103-119.

Yeung, T. C., Beaulieu, Jr, B. B., Mclafferty, M. A. \& Goldman, P. (1984). Interaction of metronidazole with DNA repair mutants of Escherichia coli. Antimicrob Agents Chemother 21, 131-134.

Zabeau, M. \& Stanley, K. K. (1982). Enhanced expression of cro- $\beta$ galactosidase fusion proteins studied under the control of the $\mathrm{Pr}$ promoter of bacteriophage $\lambda$. EMBO J 1, 1217-1224.

Zappe, H., Jones, D. T. \& Woods, D. R. (1986). Cloning and expression of Clostridium acetobutylicum endoglucanase, cellobiase and amino acid biosynthesis genes in Escberichia coli. J Gen Microbiol 132, 1367-1372

Zappe, H., Jones, D. T., Jones, W. A. \& Woods, D. R. (1988). Structure of an endo- $\beta-1,4-$ glucanase gene from Clostridium acetobutylicum P262 showing homology with endoglucanase genes from Bacillus spp. Appl Environ Microbiol 54, 1289-1292.

Zuber, P. \& Losick, R. (1987). Role of AbrB in SpoOA- and SpoOBdependent utilization of a sporulation promoter in Bacillus subtilis. $J$ Bacteriol 169, 2223-2230.

Received 24 October 1994; accepted 23 November 1994. 